\title{
OBRAZ CHIN W RAPORTACH DYPLOMATYCZNYCH STANISŁAWA PATKA Z LAT 20. XX WIEKU'
}

Polski dyplomata Stanisław Patek w jednym z raportów z 1925 r. pisał: Chiny sa wielkie, bogate i maja ludności czterysta milionów. Sa doskonatym rynkiem zbytu. Liczyć się z nimi, a nawet zabiegać o nie musza wszystkie wielkie państwa, których budżet stoi na exporcie ${ }^{2}$. Dzisiaj dodalibyśmy, że Chiny mają ponad miliard mieszkańców i liczyć się z nimi muszą już nie tylko wielkie państwa, ale dosłownie wszyscy, gdyż państwo to znajduje się w czołówce mocarstw ekonomicznych. Kim był Stanisław Patek, dlaczego opisywał Chiny i na ile jego spostrzeżenia możemy wpisywać w ciąg długofalowych procesów historycznych mających reperkusje w czasach współczesnych?

Stanisław Patek (1866-1944) był dyplomatą, politykiem i adwokatem. Od 1905 r. współpracował z Józefem Piłsudskim i jako jego przedstawiciel brał udział w konferencji pokojowej w Paryżu. W czasie wojny z bolszewikami w 1920 r. pełnił funkcję ministra spraw zagranicznych. W latach 1921-1926 był posłem w Tokio oraz do 1924 r. w Pekinie, w latach 1927-1932 w Moskwie, a w latach 1933-1936 ambasadorem w Waszyngtonie. W 1936 r. prezydent Rzeczypospolitej Polskiej

${ }^{1}$ Artykuł ten stanowi część realizowanego projektu badawczego, finansowanego przez Ministerstwo Nauki i Szkolnictwa Wyższego ze środków na naukę w latach 2008-2011 nr N N108 108434 Stanisław Patek i jego czasy - biografia Stanisława Patka (1866-1944), adwokata i dyplomaty. Problemy poruszone w artykule oraz cały okres działalności Patka zostaną szerzej omówione w przygotowywanej publikacji Stanisław Patek $w$ dyplomacji i polityce.

${ }^{2}$ Archiwum Akt Nowych (dalej: AAN), Ambasada RP w Waszyngtonie, 21, k. 11, Tokio, 6 IX 1925, raport Patka do ministra spraw zagranicznych Aleksandra Skrzyńskiego. 
powołał go do Senatu RP, gdzie Stanisław Patek działał w Komisji Spraw Zagranicznych do roku $1939^{3}$.

\section{Polska i Chiny w latach 20. XX wieku}

W literaturze przedmiotu Stanisław Patek funkcjonuje jako dyplomata pełniący funkcję posła w Tokio w latach 1921-1926. O placówce pekińskiej zazwyczaj występują tylko niewielkie wzmianki. Jest to najzupełniej uzasadnione, gdyż Polska nie utrzymywała w tamtym okresie stosunków dyplomatycznych z Chinami i Patek pełnił tam obowiązki nieformalne, półoficjalne 4 . Polska była jednak zainteresowana wysyłaniem do Chin swoich dyplomatów ze względu na przebywających tam Polaków oraz ze względu na rolę, jaką państwo to odgrywało w stosunkach międzynarodowych na Dalekim Wschodzie, w tym istotne były jego kontakty z Rosją sowiecką. Patek pisał, że na terenach wschodniej Syberii funkcjonowały jeszcze stare polskie konsulaty, Chiny zaś godzity się na to, ażeby Polska jeszcze przed podpisaniem traktatu tymczasowo $w$ centralnych punktach posiadała swoich wysokich delegatów. Poselstwo Polskie w Tokio podtrzymywało stałe stosunki i z pierwszymi, i z drugimi ${ }^{5}$, oraz że Poselstwo musiało dawać baczenie i na Chiny, z którymi jeszcze wówczas Polska nie miała zawartego traktatu, oraz na Wschodnia część Syberii, która nie była jeszcze zajęta przez bolszewików ${ }^{6}$.

Jak zostało powiedziane, Polska nie utrzymywała w tym czasie stosunków dyplomatycznych z Chinami, chociaż te uznały państwo polskie de iure 27 marca 1920 r. $^{7}$ Władze Chin przestrzegały zasady najpierw zawarcia $\mathrm{z}$ danym państwem traktatu, a potem dopiero uznawały przedstawiciela dyplomatycznego tego państwa na swoim obszarze. Polska zawarła taki traktat dopiero w latach 1928-1929. Przedtem jednak - w grudniu 1919 r. w Paryżu - pomiędzy Poselstwem Polskim w Paryżu a francuskim Ministerstwem Spraw Zagranicznych została podpisana umowa, w świetle której do momentu ustanowienia polsko-chińskich stosunków

${ }^{3}$ Szerzej Małgorzata Gmurczyk-Wrońska, Stanisław Patek-szkic do biografii: stan badań, źródła, problemy badawcze, „Dzieje Najnowsze” 2007, nr 3, s. 3-25; Stanisław Patek, Raporty i korespondencja z Moskwy (1927-1932), oprac. M. Gmurczyk-Wrońska, Neriton, Warszawa 2010.

4 AAN, Kancelaria Cywilna Naczelnika Państwa, 13, pismo Naczelnika Państwa Józefa Piłsudskiego i ministra spraw zagranicznych Skirmunta z 12 VII 1921(22?); pełnomocnictwo dla Patka jako posła w Pekinie podpisane przez Józefa Piłsudskiego i ministra spraw zagranicznych Gabriela Narutowicza z 20 X 1922.

5 S. Patek, Wspomnienia ważkich okresów pracy, Warszawa 1938, s. 22.

${ }^{6}$ Ibidem.

7 Maria Nowak-Kiełbikowa, Japonia i Chiny w dyplomacji II Rzeczypospolitej, „Dzieje Najnowsze" 1981, nr 1-2, s. 242. 
dyplomatycznych (po podpisaniu traktatu) opiekę nad polskimi obywatelami w Chinach miały sprawować oficjalnie konsulaty francuskie. Nieoficjalnie, za zgodą rządu Chin, w konsulatach tych jako „urzędach państwa opiekuńczego”, czyli Francji, mogli przebywać polscy konsulowie, i to oni wykonywali tę pracę. Działo się tak w Szanghaju, gdzie w konsulacie francuskim przebywał konsul Otto Hubicki ${ }^{8}$. Natomiast „konsulat” w Harbinie w latach 1919-1920 stanowił część „Misji Polskiej na Syberię" przy admirale Aleksandrze Kołczaku9. W grudniu 1920 r. w wyniku umowy podpisanej przez Józefa Targowskiego z chińskim Ministerstwem Spraw Zagranicznych w Pekinie pełniący obowiązki konsula Michał Morgulec objął stanowisko prowizorycznego delegata polskiego w sprawach repatriacji i opieki nad Polakami. Konsulaty te formalnie podlegały poselstwu w Tokio. W 1924 r. w Harbinie powstała Delegatura RP i Wydział Konsularny był jej częścią ${ }^{10}$. W związku z tymi zmianami Patek otrzymał w lutym 1924 r. z MSZ pismo informujące o usamodzielnieniu się placówki w Harbinie i zwolnieniu go jako posła w Tokio z obowiązków wobec Chin. Odtąd Patek nie sprawował funkcji zwierzchnich wobec placówek w Chinach, ale nadal w zakres jego obowiązków wchodziło informowanie MSZ o sytuacji w tym kraju.

Zanim jednak Stanisław Patek ograniczył swą działalność w sensie formalnym tylko do Japonii, podjął próbę uregulowania stosunków dyplomatycznych z Chinami, czyli zawarcia z tym państwem wymaganego traktatu. Wiosną 1922 r. poseł wyjechał do Pekinu „w sprawie traktatu z Chinami”"1. Prowadził tam rozmowy z ministrem doktorem Yenem i wiceministrem Shenem. Z powodu nasilenia się walk wewnętrznych w Chinach i rezygnacji z urzędu prezydenta republiki Xu Shichanga (1855-1939) pertraktacje zostały przerwane. Chińczycy zapowiedzieli jedynie Patkowi, że „gdy nadejdzie czas dla Chin odpowiedni”, chińskie MSZ miało go o tym powiadomić. Do grudnia 1923 r. nie otrzymał żadnego zawiadomienia i sprawa pertraktacji handlowych pozostawała w zawieszeniu, chociaż Patek informował, że zawarto „prowizoryczne postanowienia” ${ }^{2}$. W grudniu $1923 \mathrm{r}$. Stanisław Patek spotkał się z przebywającym w Tokio doktorem Wang Shichen-

8 X.Y.Z., Rozwój stosunków polsko-chińskich (1917-1936), „Polityka Narodów” 1937, t. 10, z. 3, s. 146-148.

9 Za Wojciech Skóra, Stużba konsularna Drugiej Rzeczypospolitej. Organizacja, kadry i dziatalność, Wydawnictwo Adam Marszałek, Toruń 2006, s. 879.

${ }^{10}$ Ibidem.

11 Jak wynika z listu Patka do posła w Waszyngtonie Kazimierza Lubomirskiego, podróż najprawdopodobniej odbyła się w miesiącach marzec - początek czerwca. AAN, Ambasada RP w Waszyngtonie, 2512, k. 38, Tokio 28 VI 1922.

12 AAN, MSZ, 7457, k. 11-12, Tokio, 17 XII 1923, raport Patka do ministra spraw zagranicznych Romana Dmowskiego. Nie udało się odnaleźć dokumentu z rozmów pekińskich Patka. 
giem (ówczesna pisownia: Wang Shih Cheng) ${ }^{13}$. Podczas spotkania dyplomata chiński nawiązał do rozmów z 1922 r. i zapytał, czy Polska „w dalszym ciągu” dąży do podpisania traktatu z Chinami. Patek odpowiedział, że Polska jest zainteresowana zawarciem traktatu tymczasowego. Motywował to nieuregulowaną sytuacją międzynarodową Chin, wynikającą z trwających jeszcze prac komisji w sprawach eksterytorialności, powołanej w czasie konferencji waszyngtońskiej. Jednocześnie Patek wskazywał na niezwykle ważny dla Polski problem ludności polskiej w Chinach, której część - jak sądził - wróci do kraju, część pozostanie w Chinach i będzie tącznikiem pomiędzy Polska i Chinami. Wskazywał także na istotę stosunków Polski i Chin - sąsiadów Rosji ${ }^{14}$. W związku z ograniczeniem od 1924 r. kompetencji poselstwa w Tokio na rzecz placówki w Harbinie Patek nie kontynuował już rozmów z Chińczykami na temat traktatu handlowego.

\section{Chiny w raportach dyplomatycznych}

W latach 20. XX w. Daleki Wschód nie odgrywał jeszcze tak dużej roli w polityce światowej jak obecnie. Zachodziły tam już jednak procesy i zjawiska istotne dla późniejszych wydarzeń II wojny światowej i jej konsekwencji w układzie międzynarodowym w drugiej połowie XX w. oraz rzutujące na naszą współczesność. Wkroczenie wojsk japońskich do Mandżurii 18 września 1931 r. stało się początkiem realizacji wielkich planów ekspansyjnych Japonii w Chinach. Skutkiem tego było zbliżanie się Tokio do polityki Berlina i Rzymu i powstanie koalicji Osi. Podzielone, a potem już zjednoczone Chiny skupiały w sobie jak w soczewce nici

${ }^{13}$ AAN, MSZ, 7457, k. 3, Tokio, 10 XII 1923, raport Patka do ministra spraw zagranicznych Romana Dmowskiego. Dr Wang Shih Cheng był członkiem delegacji chińskiej w czasie konferencji paryskiej w 1919 r. i wtedy prawdopodobnie dyplomaci się poznali. Patek pisał, że dr Wang przybył do Tokio w celu naradzenia się ,z rządem japońskim w sprawie pertraktacji z Karahanem i traktatu z Rosją".

${ }^{14}$ AAN, MSZ, 7457, k. 11-14, Tokio, 17 XII 1923, raport Patka do ministra Dmowskiego. Patek w następujący sposób opisał spotkanie z dr. Wangiem: Na zapytanie, jak sobie wyobrażam dalsze nasze stosunki, odpowiedziałem mu, że przypuszczam, iż Chiny zdażaja do tego, ażeby, tak jak wszystkie inne mocarstwa, mieć na jednych i tych samych podstawach oparte stosunki ze wszystkiemi państwami. Nie będzie państw uprzywilejowanych i nieuprzywilejowanych, nie będzie państw pierwszej i drugiej klasy, nie będzie państw z prawami eksterytorjalności i bez praw eksterytorjalności, a będzie jednakowy stosunek do wszystkich państw oparty na tych zasadach, które ma przygotowawczo opracować komisja podczas waszyngtońskiej konferencji wyłoniona, a która następnie $w$ formie ostatecznej zostana przyjęte przez mocarstwa zainteresowane. Zasady te stana się obowiazujacemi dla wszystkich, a zatem i dla Polski, obecnie zaś zadaniem naszym będzie tylko ustanowienie zasad przejściowych, obowiazujących w międzyczasie, t.j. od chwili ich podpisania do chwili przyjęcia powyżej omówionych zasad przez mocarstwa, które brały udział w konferencji waszyngtońskiej (tu i dalej pisownia oryginalna). 
polityki wielkich mocarstw, takich jak: Japonia, Rosja sowiecka, Wielka Brytania czy Stany Zjednoczone Ameryki. Chiny stawały się też coraz bardziej częścią gospodarki światowej, chociaż nie w takim stopniu jak obecnie. $Z$ dala od tych wydarzeń, ale śledząc je z uwagi na stosunki z Rosją sowiecką, pozostawała Polska.

Stanisław Patek z pozycji dyplomaty obserwował i analizował sytuację każdego z mocarstw Dalekiego Wschodu, wskazywał jednak na Chiny jako centrum stosunków międzynarodowych na Dalekim Wschodzie. To potężne imperium już w XIX w. zaczęło słabnąć, a po obaleniu monarchii w 1911 r. pogrążyło się w wojnie domowej. Do dzisiaj historycy nie znajdują jednoznacznych wyjaśnień przyczyn załamania się tego państwa na początku XX w. Wprawdzie penetracja handlowa mocarstw europejskich zaczęła się w Chinach już w XVIII w., w XIX w. Chiny z różnym skutkiem „handlowały” nie tylko z Europą, ale i ze Stanami Zjednoczonymi, ale dopiero po 1911 r. rozpoczął się okres chaosu ${ }^{15}$. Rosja, Japonia, Stany Zjednoczone i Wielka Brytania, w niewielkim stopniu Francja, dążąc do dominacji w tym państwie, wspierały często poszczególnych chińskich wojskowych lub całe stronnictwa. Rywalizacja ta przekładała się także, w formie symbolicznej, na zachowania i postawy dyplomatów w innych państwach, którzy współpracowali ze sobą i tworzyli swoiste małe koalicje. Zjawisko to Patek obserwował w łonie korpusu dyplomatycznego w Tokio. Poza Rosją przedstawiciele Anglii często wchodzili w ,sojusze” z dyplomatami z Japonii oraz Stanów Zjednoczonych, a dyplomaci z Francji z Włochami i Belgami. Patek opisywał to następująco: W obecnym stadium rozwoju stosunków międzynarodowych na Dalekim Wschodzie, na terenie Chin walcza ze soba o Chiny dwie rozbieżne sity. Jedna - Rosja, druga - to grupa państw złożona z Japonii, Stanów Zjednoczonych, Anglii etc. Chiny działajac, mogtyby znakomicie wyzyskać sytuację, gdyby nie to, że nie posiadaja swego rzadu centralnego, nie maja jednolitego programu politycznego i żyja w chaosie ciagtych walk wewnętrznych ${ }^{16}$.

Polski dyplomata twierdził, że aby Chiny nadały swej polityce podstawy state, musza odpowiedzieć sobie [...] na zasadnicze pytanie: a) czy moga swój stosunek do mocarstw obcych (z wytaczeniem Rosji) doprowadzić do ostateczności, t.j. czy moga obejść się bez nich lub walczyć z niemi? b) od kogo sa bardziej zależne

15 Już w XIX w. Chiny zgodziły się na tzw. porty traktatowe, w których w ramach eksterytorialnej jurysdykcji cudzoziemcy nie podlegali jurysdykcji chińskiej. Do $1911 \mathrm{r}$. takich portów było 92. Statki cudzoziemców wnosiły tylko niewielkie cła importowe za swe towary. Opłaty pobierała chińska Agencja Ceł Morskich, podporządkowana w praktyce Brytyjczykom. W 16 portach „traktatowych" cudzoziemcy posiadali - w ramach eksterytorialności - dzielnice, drogi, szkoły, policję. Przykładem oporu Chińczyków wobec cudzoziemców było powstanie bokserów. Szerzej Jakub Polit, Chiny, Trio, Warszawa 2004, s. 34-44.

${ }^{16}$ AAN, Ambasada RP w Waszyngtonie, 21, k. 4, Tokio, 8 VII 1925, raport Patka do ministra spraw zagranicznych Aleksandra Skrzyńskiego. 
i kto im dać może więcej: Rosja czy pozostate mocarstwa? Rosja może dać Chinom propagandę bolszewicka, a wziać wszystko co się da w Mandżurji $i$ w Mongolii. - Podczas gdy po przeprowadzeniu reform i skasowaniu praw eksterytorialności polityczne i ekonomiczne wspólżycie Chin z wielka rodzina narodów zależé będzie w pierwszej linii od Japonii, Stanów Zjednoczonych i Anglii, jako państw posiadajacych największe interesa $w$ Chinach, oraz posiadajacych łącznie z Chinami największe interesa na Pacyfiku ${ }^{17}$.

Patek nie lekceważył jednak wpływów sowieckich w Chinach, szczególnie pozycji Sowietów w Mongolii. Wręcz przeciwnie - uważał je za bardzo groźne. Z niepokojem obserwował zabiegi dyplomaty sowieckiego Lwa Karachana o zawarcie z Chinami traktatu handlowego ${ }^{18}$. Poseł sceptycznie oceniał możliwości zjednoczenia Chin $^{19}$. Sądził, że tak ogromne państwo, składające się jednak z części mogących samodzielnie funkcjonować, może trwać jeszcze długo w stanie podziałów ${ }^{20}$. Przewidując utrzymywanie rozbicia politycznego Chin, sądził, że wpływy utrzymają tam, tak jak w rejonie całego Pacyfiku, Japonia, Stany Zjednoczone i Anglia. Państwa te wprawdzie ciagna z Chin zyski, ale też musza dbać o nie, czego dowiodła konferencja waszyngtońska, kontynuując politykę otwartych drzwi w Chinach ${ }^{21}$. Ta wielość wpływów mocarstw gwarantowała utrzymanie pewnej równowagi sił w rejonie i stanowiła niejako gwarancję suwerenności dla samych Chin. Patek pisał, że państwa te moga Chiny eksploatować, a nawet wyzyskiwać niekiedy, ale nie

17 Ibidem, k. 6-7.

18 AAN, MSZ, 7457, k. 3, Tokio, 10 XII 1923, raport Patka do ministra Dmowskiego.

19 Ibidem, k. 2.

${ }^{20}$ AAN, MSZ, 7457, k. 25, Tokio, 6 XI 1924, raport Patka do ministra Skrzyńskiego. Patek pisał: Sprawa unifikacji Chin jest bardzo trudna dla tego, że Chiny, jako przestrzeń, sq wielkie i nie składaja się z takich części, które by ekonomicznie lub życiowo byly potrzebne jedne dla drugich. Części te sa w stosunku do siebie jednostkami mniej więcej wspótrzędnymi. Każda z nich jest samowystarczalna i bez drugiej obejść się może. Żadna nie jest z innemi zwiazana kompleksem bardziej zywotnych interesów. Niektóre z najwybitniejszych centrów nie sa nawet pomiędzy soba połaczone siecią kolejową. Nawet język jednych prowincji bardzo silnie różni się od języka drugich. Dla tego części te pozostają dla siebie nawzajem dalekie i unifikacja, która w pojęciu naszem jest dla każdego Państwa konieczną, dla Chińczyków niezbędna nie jest. To jest istotnem źródtem rozbieżności pojęć chińskich i europejskich.

${ }^{21}$ AAN, Ambasada RP w Waszyngtonie, 21, k. 7, Tokio, 8 VII 1925. Postanowienia konferencji waszyngtońskiej nie były dla Chin upokorzeniem. Chiny reprezentowali tam Wellington Koo i Alfred Sze. Chiny uzyskały zwrot poniemieckich terenów w Szanghaju, przyjęto postanowienie o ,nienaruszalności chińskiego terytorium" oraz obiecywano renegocjacje spraw związanych z eksterytorialnością i taryfami celnymi. Szerzej J. Polit, Chiny, s. 94. Pomysł zwołania konferencji waszyngtońskiej wyszedł od USA i Wielkiej Brytanii. Japonia została właściwie przymuszona do niej. W czasie obrad miała poparcie tylko Francji. Udział w konferencji waszyngtońskiej wzięły państwa mające posiadłości w rejonie Oceanu Spokojnego, czyli USA, Wielka Brytania, Włochy, Francja, Chiny, Holandia, Portugalia, Belgia i Japonia. 
moga nigdy dopuścić do tego, ażeby Chiny osłably aż do tego stopnia, ażeby nie mogły kupować, t.j. ażeby przestały być konsumentem ich eksportu. Musza podtrzymywać Chin istnienie, bo na tem istnieniu jest oparty rozkwit ich własnego handlu i przemystu. Musza to czynić w imię własnego interesu. $Z$ drugiej strony każde $z$ tych państw pragnęło by wzmocnić w Chinach swe wptywy i stanowisko i wskutek tego pilnuje, ażeby jego rywale nie rozwielmożnili się w nich zbytnio. To wzajemne czuwanie i rywalizacja wptywa na utrzymanie pewnej proporcji i nie pozwala, by nad Chinami zapanowała jedna jakakolwiek potęga. W ten sposób Chiny bez żadnego ze swej strony wysitku sa pod tym względem gwarantowane. Chiny aczkolwiek niezorganizowane i ciagle wewnętrzne walki prowadzace, ze wschodnia chytrościa umieja wyzyskać te swoje uprzywilejowane stanowisko w tym kierunku, ażeby jaknajwięcej otrzymać, a jaknajmniej oddać. Wszystkim sa winne, nigdy nie spiesza się z zapłata, i podejmuja wielkie larum, jeżeli zniecierpliwiony wierzyciel sięgnie zbyt energicznie po swa należność, oparta na ich skarbowych dochodach $i$ z cet, monopoli etc. Widza $w$ tem zamach na ich suwerenność lub wtracanie się do ich spraw wewnętrznych i licza, że zawsze znajdzie się jakieś zainteresowane mocarstwo, które głośno lub po cichu poprze protest ich rzadu lub społeczeństwa, które w urzadzaniu rozruchów i demonstracji jest dobrze wyszkolone $e^{22}$.

Patek traktował Chiny jako swego rodzaju fenomen w stosunkach międzynarodowych i przykład dominacji gospodarki nad respektowaniem podstawowych praw człowieka. Ze względu na niezwykle drastyczny kodeks karny, surowe więzienia, brak szacunku dla wolności jednostki i masowe egzekucje Chiny powinny być ostrożnie traktowane przez ówczesne demokracje. Tak się jednak nie działo, sprawy ekonomiczne i dążenie do dominacji w rejonie przez wielkie mocarstwa stawiały w cieniu funkcjonowanie systemu wewnętrznego w tym państwie. Patek pisał, że z chińskim kodeksem karnym oraz z ustrojem chińskiego sadownictwa, więziennictwa i administracji nie może się pogodzić zasadnicze pojęcie poszanowania swobody człowieka i jego mienia. Żadne mocarstwo nie może się zgodzić na masowe ekzekucje, na zakuwanie swych obywateli $w$ dyby drewniane lub na przetrzymywanie ich bez decyzji sadowej przez całe miesiace $w$ cuchnacych lochach więziennych ${ }^{23}$. Twierdził, że uprzywilejowaną pozycję w Chinach wśród wymienionych mocarstw miała Japonia. Silna rywalizacja japońsko-amerykańska w Chinach i dążenie do zwaśnienia Chin z Japonią doprowadzały czasami do ustępstw wobec Chińczyków ze strony Waszyngtonu. Najtrudniej było Wielkiej Brytanii rywalizować w Chinach z wpływami japońskimi i amerykańskimi, ale Patek przypuszczał, że Londyn nie pójdzie przeciwko własnym interesom handlo-

${ }^{22}$ AAN, Ambasada RP w Waszyngtonie, 21, k. 11-12, Tokio, 6 IX 1925, raport Patka do ministra Skrzyńskiego.

23 Ibidem, k. 15. 
wym i nie pójdzie na stratę swych wptywów na terenie chińskim, na którym wzmagają się w niektórych prowincjach wpływy bolszewizmu, zawsze groźnego dla Anglji ze względu na kolonje ${ }^{24}$.

Patek nie wierzył w trwałe sukcesy bolszewizmu w Chinach. Barierą według niego były ugruntowane od pokoleń stosunki rodzinne Chińczyków, oparcie się na tradycyjnych zasadach życia. Widział wprawdzie niebezpieczeństwo penetracji politycznej i gospodarczej przez Rosję sowiecką w poszczególnych rejonach Chin, w tym także na kolejach, ale nie dającej podstaw do ugruntowania przez nią tam wpływów ${ }^{25}$. Pisał, że Daleki Wschód nie jest terenem podatnym dla rozwoju indywidualizmu. Życie jest oparte na ustroju rodziny, która się rozrasta w ród, w gminę i inne zbiorowe jednostki, którym podlega każda jednostka indywidualna. Ustrój ten jest tak samorodny i twardy, że okazuje się mocniejszym od takiej czy innej formy rzadu lub ustroju politycznego. Przetrwat on burze $i$ wojny i stanie się prawdopodobnie duża naturalna przeszkoda dla rozwoju propagandy bolszewickiej ${ }^{26}$.

W 1925 r. w Chinach miały miejsce antycudzoziemskie manifestacje. Wynikały one z walk wewnętrznych, ale były także odbiciem nastrojów wobec obcych. W historiografii wydarzenia lat 1925-1927 w Chinach zostały określone jako rewolucja narodowa. Ogromna fala manifestacji połączona z walkami, głównie z Brytyjczykami, ale i z Amerykanami i Japończykami, ogarnęła Chiny po śmierci Sun Yat-sena ${ }^{27}$ oraz po starciach studentów i robotników z policją w Szanghaju 30 maja 1925 r. (Ruch 30 Maja). Po starciach z Brytyjczykami Chińczycy przez ponad rok bojkotowali ich towary. Sytuację tę świetnie wykorzystywali Sowieci, wysyłając swych przedstawicieli jako doradców i wspierając militarnie zwaśnione strony. Zwycięstwo w walkach o dominację w Chinach odniósł w 1927 r. ruch narodowy Czang Kaj-szeka, komuniści wspierani przez Moskwę zostali osłabieni ${ }^{28}$.

${ }^{24}$ Ibidem, k. 13.

${ }^{25}$ AAN, MSZ, 7457, k. 26, Tokio, 6 XI 1924, raport Patka do ministra Skrzyńskiego.

${ }^{26}$ Ibidem.

27 Sun Yat-sen (1866-1925) nazywany jest ojcem republiki chińskiej, dążył do zjednoczenia Chin pod hasłami panazjatyckimi i antykolonialnymi, zwracał się o pomoc do Wielkiej Brytanii, USA i w końcu do ZSRR. Korzystając ze wsparcia bolszewików, włączył swą działalność do partii Guomindangu, skupiającej zarówno siły narodowe, jak i komunistyczne. Moskwa wspierała wprawdzie Guomindang, ale jednocześnie prowadziła pertraktacje z rywalem Suna, chińskim rządem w Pekinie. To z rządem chińskim 31 maja 1924 r. ZSRR nawiązał stosunki dyplomatyczne. Sun Yat-sen zmarł w marcu 1925 r.

28 Szerzej J. Polit, Chiny, s. 102-119; idem, Wielka Brytania i klęska Kominternu w Chinach (1927), [w:] Artur Patek, Wojciech Rojek (red.), Naród-państwo. Europa Środkowa w XIX i XX wieku. Studia ofiarowane Michałowi Pułaskiemu w pięćdziesięciolecie pracy naukowej, Wydawnictwo Uniwersytetu Jagiellońskiego, Kraków 2006, s. 273-282. Po śmierci Sun Yat-sena Sowieci w osobie Michaiła Borodina (działacz Kominternu) przystąpili do reorganizacji Guomindangu według własnych wzorów. To oni wyszkolili dowodzoną przez Czang Kaj-szeka Armię Narodowo-Rewolucyjną 
Patek słusznie określał te wystąpienia jako ruchy związane $\mathrm{z}$ „młodochińskim nacjonalizmem" oraz zupełnie odmiennym i sprzecznym z nim ruchem powstałym pod wpływem sowieckiej „,czerwonej propagandy”29. Podczas manifestacji Chińczycy domagali się między innymi respektowania przez mocarstwa takich obietnic konferencji waszyngtońskiej jak autonomia celna czy zniesienie eksterytorialności dla cudzoziemców. Reakcja ze strony zainteresowanych mocarstw była prawie natychmiastowa, chociaż nie taka, jakiej oczekiwali Chińczycy. Patek twierdził, że wprawdzie mocarstwa nie mogły uchylać się od wypełniania postanowień konferencji waszyngtońskiej, ale nie chciały tego czynić pod wpływem manifestantów. Zainteresowane mocarstwa zaczęły działać dwutorowo. Uruchomiono proces realizacji postanowień konferencji waszyngtońskiej i tym samym zniwelowano główne żądania manifestantów oraz postanowiono powołać specjalną międzynarodową komisję arbitrów z uprawnieniami sądu do zbadania samych antycudzoziemskich wystąpień jako „zwykłych rozruchów”. W skład czteroosobowej komisji weszli prawnicy, przedstawiciele Japonii, Stanów Zjednoczonych, Wielkiej Brytanii i Chin. Największe problemy były z wyznaczeniem przedstawiciela przez Chiny. Patek pisał, że to tłomaczy się tym, że Chiny już w tej chwili posiadaja dogodne dla siebie pierwsze orzeczenie ciała dyplomatycznego, więc nie bardzo spiesza się z ponownem oddawaniem swoich ludzi pod sąd cudzoziemskiego areopagu $u^{30}$. Wspomniane „orzeczenie ciała dyplomatycznego” dotyczyło uruchomionego procesu wdrażania postanowień konferencji waszyngtońskiej i wiązało się z dość pomyślnymi dla Chin propozycjami dotyczącymi spraw celnych. Gorzej wyglądały problemy eksterytorialności. Teoretycznie mocarstwa zgadzały się na rezygnację z tego prawa, ale z obawy o przejście pod władanie chińskiego prawodawstwa, sądownictwa i więziennictwa domagały się od Chin reform w tych dziedzinach. Doszło więc do sytuacji paradoksalnej. Komisja w sprawie eksterytorialności wyrażała gotowość przystąpienia do prac, Chińczycy domagali się odroczenia rozpoczęcia posiedzenia ${ }^{31}$.

Opisując sytuację w Chinach, Patek oddzielnie analizował Chiny centralne z Pekinem, prezydentem i rządem (tam znajdowali się przedstawiciele dyplomatyczni), północne z Mukdenem rządzone przez Zhang Zuolina oraz południowe z Kantonem i Sun Yat-senem. Poseł uważał, że najlepszym administratorem w europejskim znaczeniu tego słowa był Zhang Zuolin. Widział w nim wytrawnego polityka

Guomindangu. Autor pisze, że to Sowieci skierowali ruchy protestacyjne przeciwko Brytyjczykom jako swoim największym rywalom na Dalekim Wschodzie (Persja, Afganistan, Indie). Brytyjczycy ponieśli ogromne straty handlowe w Chinach.

29 AAN, Ambasada RP w Waszyngtonie, 21, k. 17, Tokio, 18 IX 1925, raport Patka do ministra Skrzyńskiego.

30 Ibidem.

${ }^{31}$ Ibidem, k. 19. 
i wojskowego, umiejętnie zarządzającego podległym mu obszarem. Zachowując niezależność, potrafił współpracować ze specjalistami z Japonii i Rosji. Krytycznie oceniał Patek prezydenta Cao Kuna, uzależnionego od generała Wu Peifu. Ironizował na temat błędnej w jego ocenie diagnozy sytuacji w Chinach postawionej przez Wielką Brytanię i Stany Zjednoczone. Pisał, że państwa te po zwycięstwie Wu Peifu w 1922 r. miały nadzieję na zjednoczenie Chin wokół ośrodka pekińskiego, który pozwoliłby im „eksploatować je spokojnie”. Poseł krytycznie pisał także o Sun Yat-senie jako „lichym” administratorze i organizatorze sił wojskowych $^{32}$. Dodajmy, że w końcu października 1924 r. walki wewnętrzne w Chinach nasiliły się i prezydent Cao Kun został obalony, a władzę w Pekinie przejął generał Feng Yuxiang, który przyciągnął do współpracy Sun Yat-sena. Politycy ci kontynuowali politykę zbliżenia z ZSRR.

Władzę autonomiczną w Mandżurii zachował do 1928 r. popierany przez Japonię Zhang Zuolin. Dodajmy także, że ZSRR zerwał na krótko stosunki dyplomatyczne z Chinami w 1929 r., po opanowaniu Mandżurii przez wojska rządzącego od 1927 r. Chinami Czang Kaj-szeka i przejęciu przez niego kontroli nad koleją. Do konfliktu sowiecko-chińskiego włączyły się wtedy USA, Wielka Brytania, Francja, Włochy i Japonia. 22 grudnia 1929 r. Chiny i ZSRR podpisały w Chabarowsku tzw. protokół chabarowski, w którym przywrócono wspólny zarząd nad koleją i przywrócono stosunki dyplomatyczne. Krótkie wprawdzie zerwanie stosunków na linii Moskwa-Pekin, a także każde nieporozumienie sowiecko-chińskie, były zawsze mile widziane $w$ Tokjo ${ }^{33}$.

W latach 1927-1932 Stanisław Patek pełnił funkcję posła w Moskwie. Stamtąd śledził wydarzenia na Dalekim Wschodzie, a szczególnie stosunki sowiecko-chińskie, japońsko-chińskie i sowiecko-japońskie. Przedmiotem ciągłych rozmów chińsko-sowieckich były kwestie Kolei Wschodniochińskiej. Chińczycy dążyli do pomniejszenia wpływów sowieckich na kolei i traktowali sprawy wspólnego zarządu nad nią jako temat do dalszych pertraktacji. Przyglądali się temu Japończycy, którzy zajmowali stanowisko coraz bardziej prosowieckie i nie przeszkadzały im już wpływy Moskwy na Kolei Wschodniochińskiej. Traktowali to raczej jako fakt mogący im ułatwić manewrowanie w skomplikowanych stosunkach z Chinami ${ }^{34}$. Kiedy 18 września 1931 r. wojska japońskie wkroczyły do Mandżurii, nie opanowały Kolei Wschodniochińskiej, aby nie psuć stosunków z ZSRR ${ }^{35}$. Moskwa natomiast zajęła niezwykle krytyczne stanowisko wobec posunięć Japonii w Mandżurii. Już

32 AAN, MSZ, 7457, k. 24-25, Tokio, 6 XI 1924, raport Patka do ministra Skrzyńskiego.

33 S. Patek, Raporty i korespondencja z Moskwy (1927-1932), dok. 199, s. 425, Moskwa 31 III 1931, raport Patka do ministra Zaleskiego.

34 Ibidem, dok. 207, s. 439, Moskwa, 16 VI 1931, raport Patka do Zaleskiego.

35 Ibidem, dok. 211, s. 446, Moskwa, 10 XI 1931, raport Patka do Zaleskiego. 
wtedy prasa sowiecka pisała, że okupacja Mandżurji nie jest wydarzeniem o znaczeniu lokalnym: Mandżurja ma przedewszystkiem znaczenie jako jeden z najważniejszych punktów strategicznych Oceanu Spokojnego i walka o hegemonję na tym terenie nabiera charakteru międzynarodowego, przyczem nieuchronnie jest zwiazana z przygotowaniami do nowej wojny światowej ${ }^{36}$. Patek, przytaczając ten komentarz z prasy, nie dodał własnej opinii.

Analizując jego raporty na temat konfliktu japońsko-chińskiego, można dostrzec obawy przed rozszerzaniem się konfliktu, próbę zachowania neutralności wobec działań Japonii, ale przede wszystkim niezwykłe wyczulenie na reakcje Moskwy. Postawa i reakcja Patka była zbliżona do reakcji polskiego MSZ. Kiedy 10 października 1931 r. przedstawiciel Chin złożył protest przeciwko Japonii na forum Ligi Narodów i poprosił o interwencję, delegacja polska, uznając odrębność sytuacji na Dalekim Wschodzie i mając zrozumienie dla specjalnych uprawnień i interesów Japonji w Mandżurji, starała się, gdy okoliczności na to pozwalały $w$ Genewie, ułatwić stanowisko Delegacji Japońskiej ${ }^{37}$. Zachowanie Polski wynikało z tradycyjnego życzliwego stanowiska wobec Japonii. Państwo to bowiem, ze względu na sąsiedztwo najpierw z Rosją carską, a potem sowiecką, stanowiło ważny czynnik w kalkulacjach polityczno-strategicznych Józefa Piłsudskiego. Polska dyplomacja, w tym Patek, dawała odczuć stronie japońskiej zdziwienie jej brakiem zainteresowania ściślejszą współpracą z Polską. W cytowanym dokumencie czytamy także: opinja japońska odnosi się do nas przyjaźnie, chociaż nie można u niej stwierdzić właściwego zainteresowania politycznego dla Polski jako zachodniego sąsiada Sowietów. To samo można naogót też powiedzieć o japońskim ministerstwie spraw zagranicznych. Większe zrozumienie pod tym względem okazuje japoński sztab generalny, który manifestuje chęć wspótpracy ${ }^{38}$.

Kilka miesięcy po przybyciu do Tokio Patek napisał ciekawy raport, który zatytułował Polityka kolejowa poszczególnych mocarstw na Dalekim Wschodzie ${ }^{39}$. Wskazywał w nim na łączność pomiędzy rozwojem (przebiegiem) linii kolejowych a polityką mocarstw uwarunkowaną kwestiami ekonomicznymi i strategicznymi. Na Dalekim Wschodzie obserwował to na przykładzie Rosji w jej rozgrywkach z Japonią i Chinami (linia syberyjska od Władywostoku i Chabarowska oraz do

${ }^{36}$ Ibidem, s. 447.

37 AAN, MSZ, 600, k. 110, wewnętrzne pismo MSZ bez daty (prawdopodobnie koniec 1933 r. lub początek 1934 r.), podpis nieczytelny. Rada Ligi Narodów podjęła początkowo decyzję nakazującą opuszczenie Mandżurii Południowej przez wojska Japonii, potem nakazała obu stronom powstrzymać się od działań zbrojnych na terenie Mandżurii i postanowiła powołać komisję badającą konflikt japońsko-chiński. Jednak faktycznie, poza deklaracjami, nie uczyniła w tej sprawie nic.

${ }^{38}$ Ibidem.

39 AAN, Ambasada RP w Moskwie, 1, k. 2-9, Tokio, 13 XII 1921 (odpis), podpis Patka, ale bez adresata. 
Moskwy i Petersburga oraz inne linie), Stanów Zjednoczonych skonfliktowanych z Japonią i dążących do dominacji w Chinach, a także stosunków chińsko-japońskich. Patek śledził od dawna problem znaczenia kolejnictwa w stosunkach międzynarodowych, widział, jakie miejsce zajmowały te kwestie w traktatach pokojowych. Konstatował, że linie kolejowe same w sobie stanowia system polityczny, odzwierciedlają wpływy danego mocarstwa i ilustrują rywalizację pomiędzy nimi, są tącznikiem pomiędzy najbogatszymi prowincjami Dalekiego Wschodu, a cała Europa ${ }^{40}$. Patek niezwykle precyzyjnie opisywał powstawanie, istnienie i znaczenie polityczno-ekonomiczno-strategiczne poszczególnych odcinków linii kolejowych. Na przykład w 1925 r. w czasie nasilających się w Chinach walk wewnętrznych pisał: Feng [generał Feng Yuxiang, znany jako „chrześcijański generał, sympatyzujący z Rosją”] sam przez się nie jest dla Czang-tso-lina [Zhang Zuolin, ,„przyjaciel Japonii"] przeciwnikiem groźnym, o ile nie stoi za nim Rosja, a przeciwko Rosji tak czy inaczej Czang-tso-lin musi przybrać odporna postawę wobec sprzeczności interesów chińskich i rosyjskich w Mandżurji, która Czang-tso-lin rządzi i w Mongolji, na która pragnie rozszerzyć swa wtadzę. Dwie obecnie projektowane linje kolejowe od Kirynu do Kaigunnen i od Tuonanu do Tsitsiharu wzmocnia jego pozycje pod względem handlowo-ekonomicznym i stworza pewne udogodnienie pod względem strategicznym. - Czuje to dobrze Rosja, dlatego zgłosita protest co do linji Tuonan-Tsitsihar [...]. W sprawie linji Tuonan-Tsitsihar jest specjalnie zainteresowana Japonja, gdyz posiada umowe co do jej finansowania i budowy ${ }^{41}$. Przypomnijmy, że po 1905 r. Japonia przyłączyła Półwysep Liaotuński i Koreę oraz linię południowomandżurską. Japonia dążyła do objęcia swymi wpływami terenów południowych i wyparcia stamtąd wpływów USA i Wielkiej Brytanii. Zhang Zuolin, sympatyzujący z Japonią, ale lojalny wobec władz w Pekinie, od 1919 r. sprawował władzę w Mandżurii. Powtórzmy, że Patek uważał go za „najwybitniejszą osobistość” w Chinach, którą poważali zarówno Chińczycy, jak i „obcy”.

Sądzę, że ten krótki i wyrywkowy opis raportów polskiego dyplomaty wskazuje, przynajmniej w części, na niezwykle ważną rolę Chin w stosunkach międzynarodowych w latach 20. XX w. Stanisław Patek opisywał Chiny w czasie, kiedy były podzielone wewnętrznie, penetrowane i w pewnym stopniu uzależnione od mocarstw. Potrafiły one jednak wykorzystać swój potencjał polityczny i ekonomiczny oraz spryt do manewrowania, wygrywania na rywalizacji innych. Chiny były już wtedy jednym z ważniejszych aktorów w stosunkach międzynarodowych.

${ }^{40}$ Ibidem, k. 4.

${ }^{41}$ AAN, Ambasada RP w Waszyngtonie, k. 5, Tokio, 8 VII 1925, raport Patka do ministra Skrzyńskiego (odpis). 